\title{
Periodontal Diseases in Pregnant Women in Prenatal Consultation
}

\author{
Ekofo Edize ${ }^{*}$, Nyimi Bushabu Fidele2,3, Mbungu Mwimba4, Mantshumba Milolo Augustin ${ }^{3,5}$, \\ Em Kalala Kazadi1, Sekele Isourady Bourley3,5
}

${ }^{1}$ Department of Dental Medicine, Periodontology Unit, Faculty of Medicine, Kinshasa University, Kinshasa, Democratic Republic of Congo

${ }^{2}$ Department of Dental Medicine, Oral and Maxillofacial Surgery Service, Faculty of Medicine, Kinshasa University, Kinshasa, Democratic Republic of Congo

${ }^{3}$ National Center Laboratory of Oral Biomedicine Ministry of Research Innovation and Technology, Kinshasa, Democratic Republic of Congo

${ }^{4}$ Department of Gynecology, Faculty of Medicine, University of Kinshasa, Kinshasa, Democratic Republic of Congo

${ }^{5}$ Department of Dental Medicine, Prosthodontics and Orthodontics Service, Faculty of Medicine, University of Kinshasa,

Kinshasa, Democratic Republic of Congo

Email: *yedizekofo@gmail.com

How to cite this paper: Edize, E., Fidele, N.B., Mwimba, M., Augustin, M.M., Kazadi, E.K. and Bourley, S.I. (2021) Periodontal Diseases in Pregnant Women in Prenatal Consultation. Open Journal of Stomatology, 11, 349-359.

https://doi.org/10.4236/ojst.2021.119031

Received: June 9, 2021

Accepted: September 10, 2021

Published: September 13, 2021

Copyright $\odot 2021$ by author(s) and Scientific Research Publishing Inc. This work is licensed under the Creative Commons Attribution International License (CC BY 4.0).

http://creativecommons.org/licenses/by/4.0/

(c) (i) Open Access

\begin{abstract}
Background: The relationship between pregnancy and periodontal health had well documented in the literature. Of many studies of periodontal diseases in the Democratic Republic of Congo, no study had evaluated these diseases in pregnant women during Prenatal Consultation (PC). This study aimed to describe the occurrence and clinical profile of periodontal diseases in pregnant women admitted to the PC at the General Military Hospital of BOBILA. Materials and Methods: It is a cross-sectional and analytical study of pregnant women admitted to the PC from August to December 31, 2018, at the General Reference Military Hospital of BOBILA/Kinshasa City. The data were collected through a survey combined with the stomatological interview. Sociodemographic data, clinical and periodontal indices included Oral Hygiene Index Simplified (OHI-S), Bleeding on Probing (BOP), and Periodontal Disease Index (PDI) were assessed. The statistical analyses were carried out using the SPSS version 20.0 software. The Chi-square tests, Student t-test were used to determine differences in the distribution of variables, and the odd Ratio with a confidence interval (IC) at $95 \%$ was used to estimate the degree of association. The results were significant at $\mathrm{p}<0.05$. Results: Of the 105 pregnant women received at the PC, 83 were included in this study. The age group between 20 29 was the most represented, with a predominance of stay-at-home mothers (75.9\%) and married cases (73.4\%), they had an average economic status (56.6\%) and a secondary education level (63.8\%). Gingival bleeding (44.6\%) was the main complaint of the pregnant. Gestational age was a significant
\end{abstract}


factor associated with gum bleeding $(\mathrm{p}<0.005)$. Most of the pregnant had poor oral hygiene, localized gravidities $(69.6 \%)$ during the third semester. Conclusion: A significant proportion of women had experienced periodontal diseases during the pregnancy period, mostly in the third trimester, and was associated with a gestational age of pregnant women.

\section{Keywords}

Periodontal Diseases, Clinical Profile, Pregnant Women

\section{Introduction}

Pregnancy is a modified physiological condition that had the repercussion on the oral cavity in general and periodontal tissues in particular [1]. The microbial factor is the main cause etiologic of periodontal diseases with associating local or general risk factors [2]. These risk factors include sex, age, occlusal trauma, ethnicities, low-level education, poor economic status, smoking, poor oral hygiene, systemic diseases, gestational age, and hormonal variation (progesterone and estrogen) [2] [3]. Increased levels of estrogen and progesterone raise awareness of the gum and periodontal, resulting in hypervascularization, an edematous and congestive state of periodontal tissues. These hormonal changes weaken periodontal tissues and lead to inflammation of the gums, gum bleeding, gum hyperplasia, dental mobility, or tooth loss [4] [5].

The relationship between pregnancy and periodontal health has been well documented in the literature [6]. Indeed, several studies have shown high frequencies and variables depending on the environment. The frequency of $11 \%$ $75 \%$ has been reported in America [7], 30\% -70\% in Europe [8], 11\% - 76\% in Asia [9] and 4\% - 67\% in Africa [10] [11]. Periodontal diseases serve both as reservoirs of bacteria, which can migrate and reach the placental barrier of the fetus [12]. Premature birth [13], low infant weight [14] [15] [16], increased time at conception [17] and premature rupture of the membrane [18] have been reported and attributed to the presence of periodontal diseases in pregnant women. Of several studies of periodontal disease published in the Democratic Republic of Congo [19] [20], non-one has evaluated these pathologies in pregnant women in PC care.

This study aimed to determine the prevalence of periodontal diseases during pregnancy and to identify the different risk factors for these diseases in pregnant women.

\section{Materials and Methods}

It is a cross-sectional and analytical study based on the observation of the pregnant women consulted over a period from August to December 31, 2018, was conducted. A pre-established survey for this study combined with a stomatological examination was used. The study population was all pregnant women ad- 
mitted to prenatal consultation at the General Reference Military Hospital of BOBILA (GRHB)/Kinshasa City. Included in the study was the pregnant woman attending the GRHB (Camp KOKOLO) who freely given informed consent, responded to the survey questionnaire, and underwent a stomatological examination. However, any pregnant woman who responded to the interview, but did not give initially information about her oral hygiene before pregnancy, had a prosthesis, had taken antibiotics for the last 3 months, and was treated for periodontal diseases were excluded from the study. The sample size was calculated using the following formula: $n \geq\left(Z^{2} \times p(1-p) / d^{2}\right.$ in with n: Represent the sample size; $Z$ : Confidence level according to the normal distribution (at 95\%, $Z=$ $1.96)$; $p$ : Estimated proportion of the population $(p=4 \%)$ and $\mathrm{d}$ : Tolerated margin of error (5\%). Because of lacking study evaluated the frequency of periodontal disease during pregnancy in our country, the present study referred to the frequency of $4 \%$ reported by Cheikh Tidiane CISSE, 2015 in Dakar, which the population is close to that of DRC. After applying the formula, a size of 59 pregnant women was obtained and extended to 83 pregnant women. The interesting variables were socio-demographic data and anamnestic information. On clinical examination, the Oral Hygiene Index Simplified (OHI-S), Bleeding on Probing (BOP), and Periodontal Disease Index (PDI) indices were assessed for periodontal status. Greene and Vermillion's Oral Hygiene Index Simplified (OHI-S) (1964) was used. Patient recruitment was done every day of consultation in the GRHB according to the availability of the specialists working in this Hospital. The data was collected during the consultations. Firstly, the socio-demographic data, clinical and risk factors data were collected during the interview. In the second step, the clinical examination of the oral cavity was carried out, and thirdly, the assessment of periodontal status by various index scores was evaluated. According to the OHI-S index, the examination was done on the faces of the following six teeth: 16-11-26-36-31-41. The index is composed of two elements: the debris index and the tartar index. The debris index score (DI) was scored as follows: 0: No deposits; 1 : Invisible deposit; 2: Deposits less than $2 / 3$ of the cervical tooth and 3: Deposits greater than $2 / 3$ of the cervical tooth. The tartar index (TI) was scored as 0: no pie; 1 : Tartar no more than $0.5 \mathrm{~mm}$ of thickness; 2: Tartar no more than $1 \mathrm{~mm}$ thickness; 3: Tartar more than $1 \mathrm{~mm}$ thickness. On the Greene and Vermillon scale, each patient's hygiene was determined as follows: Perfect: 0; good: 0.1 - 1.0; satisfactory: $1.1-2.0$ and bad: $2.1-6.0$. BOP was calculated as the sum of the surfaces that bled after probing divided by the number of the surfaces examined. The bleeding was assessed 20 seconds after the passage of a periodontal probe into the sulcus. The examination started on the distobuccal surface of the maxillary right second molar and continued anteriorly to the distobuccal surface of the maxillary left second molar. Then, the distolingual surface of the maxillary right second molar was examined to the distolingual surface of the maxillary left second molar. The mandibular teeth were then examined in the same manner, starting on the distobuccal surface of the mandibular right second molar. The degree of Bleeding on Probing (BOP) index 
was as 1: No bleeding in the survey; 2: Bleeding in the survey. The diagnosis of gingivitis was made if the gingival index was above $10 \%$ or the BOP index is above $10 \%$ with survey values in the normal range. Gingivitis was classified either localized (BOP score $\geq 10 \%$ and $\leq 30 \%$ ) or generalized (BOP score $>30 \%$, $\mathrm{PP}<4 \mathrm{~mm}$ and PA interproximal $<3 \mathrm{~mm}$ on all sites). The PDI index is to measure gingivitis and periodontitis. Scores determine it: 1 to $3 \mathrm{~mm}$ : Gingivitis, and 4 to $6 \mathrm{~mm}$ : Periodontitis. The Chi-square tests, the Student t-test were used to determine differences in the distribution of variables. Univariate and multivariate analysis was used to determine the factors associated with periodontal diseases. The calculation of the odd Ratio with a confidence interval (IC) at 95\% was used to estimate the degree of association. The results were significant at $\mathrm{p}<0.05$.

\section{Results}

Out of 105 pregnant women, 83 cases of well-documented pregnant women were included. The most age group of the pregnant women was 20 - 29 age year, with a predominance of stay-at-home mothers (75.9\%) and married cases $(73.4 \%)$. They had an average economic status (56.6\%) and a secondary education level of 63.8\% (Table 1). Table 2 shows that age, marital status, socioeconomic level,

Table 1. Effective of pregnant according to sociodemographic variables.

\begin{tabular}{|c|c|c|}
\hline Variables & Effective & Pourcentage \\
\hline \multicolumn{3}{|l|}{ Age group } \\
\hline $14-19$ ans & 14 & 16.9 \\
\hline $20-29$ ans & 40 & 48.2 \\
\hline $30-39$ ans & 27 & 32.5 \\
\hline $40-49$ ans & 2 & 2.4 \\
\hline \multicolumn{3}{|c|}{ Statut matrimonial } \\
\hline Single & 22 & 26 \\
\hline Maried & 61 & 73.4 \\
\hline \multicolumn{3}{|l|}{ Occupations } \\
\hline Housewife & 63 & 75.9 \\
\hline Student & 06 & 7.2 \\
\hline Officers & 14 & 16.9 \\
\hline \multicolumn{3}{|c|}{ Living standards } \\
\hline Low & 23 & 27.7 \\
\hline Average & 47 & 56.6 \\
\hline Average high & 13 & 15.7 \\
\hline \multicolumn{3}{|l|}{ Education level } \\
\hline Nonlevel & 2 & 2.4 \\
\hline Primary & 11 & 13.3 \\
\hline High School & 53 & 63.8 \\
\hline University & 17 & 20.5 \\
\hline
\end{tabular}


Table 2. Gingival bleeding, and demographic and clinical variables.

\begin{tabular}{|c|c|c|c|c|}
\hline Variables & $\begin{array}{c}\text { Total } \\
\text { Population } \\
83(100 \%)\end{array}$ & $\begin{array}{c}\text { Population } \\
\text { with gingival } \\
\text { bleeding } \mathrm{N}(\%)\end{array}$ & $\begin{array}{c}\text { Population } \\
\text { without gingival } \\
\text { bleeding } \mathrm{N}(\%)\end{array}$ & P-value \\
\hline Age & & & & 0.116 \\
\hline $14-29$ & $54(65)$ & $22(40.7)$ & $32(54.3$ & \\
\hline $30-49$ & $29(34.9)$ & $15(65.1)$ & $14(34.9)$ & \\
\hline Level of Study & & & & 0.003 \\
\hline Nonlevel & $2(2.4)$ & $0(0)$ & $2(100)$ & \\
\hline Primary & $11(13.3)$ & $5(45.5)$ & $6(55.5)$ & \\
\hline High School & $53(63.9)$ & $25(47.2)$ & $28(53.8)$ & \\
\hline University & $17(20.4)$ & $7(42.2)$ & $10(58.8)$ & \\
\hline Status matrimonial & & & & 0.234 \\
\hline Single & $22(26.5)$ & $12(54.4)$ & $10(46.6)$ & \\
\hline Married & $61(73.5)$ & $25(40.9)$ & $36(59.1)$ & \\
\hline Living hardstand & & & & 0.452 \\
\hline Low & $21(25.3)$ & $8(21.6)$ & $13(28.3)$ & \\
\hline Average & $49(59)$ & $22(59.4)$ & $27(58.7)$ & \\
\hline Average high & $13(15.7)$ & $7(18.4)$ & $6(13)$ & \\
\hline Occupation & & & & 0.542 \\
\hline Housewife & $63(75.9)$ & $27(42.8)$ & $36(58.2)$ & \\
\hline Student & $6(7.2)$ & $3(50)$ & $3(50)$ & \\
\hline Officers & $14(16.9)$ & $7(50)$ & $7(50)$ & \\
\hline Gestity & & & & 0.336 \\
\hline $1-3$ & $60(72.3)$ & $26(43.3)$ & $34(56.6)$ & \\
\hline 4 et plus & $23(27.7)$ & $11(47.7)$ & $12(43.4)$ & \\
\hline Gestational age & & & & 0.002 \\
\hline First trimester & $10(12.1)$ & $5(50)$ & $5(50)$ & \\
\hline Second trimester & $23(27.7)$ & $16(69.6)$ & $7(30.4)$ & \\
\hline Third trimester & $50(60.2)$ & $16(32)$ & $34(68)$ & \\
\hline
\end{tabular}

occupation, and gestity were not associated with significant differences between the pregnant women with gingival bleeding and those without gingival bleeding. However, a statistically significant difference was found between the pregnant women with or without gingival bleeding for education level and gestational age variables $(\mathrm{p}<0.005)$. On the univariate analysis, the association between gingival bleeding and non-level of study, low living standard ad gestational age at the third trimester was found. However, the only independent factor associated with gingival bleeding on the multivariate analysis was the gestational age of the pregnant women $\mathrm{p}<0.005$ (Table 3). Most of the pregnant women had been an age range of $14-29$ years, an average economic status, poor oral hygiene, had 
Table 3. Associated factors of gingival bleeding during the pregnancy.

\begin{tabular}{|c|c|c|c|c|c|c|}
\hline \multirow[t]{2}{*}{ Variables } & \multicolumn{3}{|c|}{ Analyse univariée } & \multicolumn{3}{|c|}{ Analyse Multivariée } \\
\hline & $\beta$ & $P$ & OR (95\% IC) & $\beta$ & $P$ & OR (95\% IC) \\
\hline \multicolumn{7}{|l|}{ Age } \\
\hline $14-29$ & & & 1 & & & 1 \\
\hline $30-49$ & 0.032 & 0.401 & $1.03(0.54-1.43)$ & 0.297 & 0.267 & $1.20(0.64-2.12)$ \\
\hline Level of Study & 1 & & & & & 1 \\
\hline Nonlevel & 1.020 & 0.011 & $2.61(1.18-5.80)$ & & & \\
\hline Primary & 0.101 & 0.667 & $1.11(0.71-1.84)$ & 0.670 & 0.153 & $1.96(0.74-4.60)$ \\
\hline University & 0.249 & 0.454 & $1.76(0.78-4.90)$ & 0.175 & 0.500 & $1.19(0.72-1.98)$ \\
\hline Status matrimonial & & & 1 & & & 1 \\
\hline single & 0.111 & 0.542 & $1.13(0.61-1.65)$ & 0.215 & 0.122 & $0.256(0.161-0.410)$ \\
\hline Married & & & & & & 1 \\
\hline Living Standards & & & 1 & & & \\
\hline Low & 1.112 & 0.031 & $1.50(1.18-5.60)$ & & & \\
\hline Average & 0.100 & 0.402 & $1.13(0.71-1.74)$ & 0.033 & 0.532 & $0.560(0.773-3.552)$ \\
\hline High average & 0.211 & 0.211 & $1.54(0.78-4.50)$ & 0.420 & 0.153 & $0.605(0.311-1.506)$ \\
\hline \multicolumn{7}{|l|}{ Occupation } \\
\hline Housewife & & & 1 & & & 1 \\
\hline Student & 0.231 & 0.592 & $1.15(0.75-1.64)$ & 0.526 & 0.223 & $0.430(0.561-1.272)$ \\
\hline Officers & 0.175 & 0.500 & $1.16(0.52-1.58)$ & & & \\
\hline \multicolumn{7}{|l|}{ Gestity } \\
\hline 1 & & & 1 & & & \\
\hline $2-3$ & 0.212 & 0.431 & $1.20(1.19-5.80)$ & & & 1 \\
\hline Superior to 3 & 0.602 & 0.512 & $1.14(0.51-1.66)$ & 0.022 & 0.331 & $0.506(0.703-3.512)$ \\
\hline \multicolumn{7}{|l|}{ Gestational age } \\
\hline First trimester & & & 1 & & & \\
\hline Second trimester & 0.247 & 0.273 & $1.25(0.88-2.44)$ & & & 1 \\
\hline Third trimester & 0.592 & 0.025 & $2.70(1.08-3.04)$ & 1.026 & 0.001 & $2.79(1.68-4.64)$ \\
\hline
\end{tabular}

localized gravidities gingivitis without loss of attachment in the $3^{\text {rd }}$ trimester (Table 4). Oral hygiene of pregnant women was poor for all trimesters but with a predominance in the third semester, including generalized gingivitis and periodontitis. The number of gestity less than four was correlated with localized bleeding gingivitis Index and with a bad OHI-S index. Mean that, the bleeding gingivitis Index and oral hygiene Index is without causing a problem when increasing the number of gestity of pregnant women.

\section{Discussion}

Studies on periodontal diseases in the Democratic Republic of Congo exist; however, no studies to date have evaluated these pathologies in pregnant women. 
Table 4. Differents indices and demographics et clinical variables.

\begin{tabular}{|c|c|c|c|c|c|c|c|c|c|c|}
\hline \multirow[b]{2}{*}{ Variables } & \multirow{2}{*}{$\begin{array}{c}\text { Total } \\
\text { Population } \\
\text { N (\%) }\end{array}$} & \multicolumn{3}{|c|}{ Bleeding Indice (BPO) $\mathrm{N}(\%)$} & \multicolumn{4}{|c|}{$\begin{array}{l}\text { Oral hygiene Indice (OHI-S) } \\
\qquad \mathrm{N}(\%)\end{array}$} & \multicolumn{2}{|c|}{$\begin{array}{l}\text { Periodontal disease } \\
\text { index (PDI) N (\%) }\end{array}$} \\
\hline & & $\leq 10 \%$ & $\begin{array}{l}\geq 10 \% \\
\leq 30 \%\end{array}$ & $\geq 30 \%$ & Perfect & Good & Satisfied & $\mathrm{Bad}$ & $1-3 \mathrm{~mm}$ & $\begin{array}{l}4-6 \\
\mathrm{~mm}\end{array}$ \\
\hline \multicolumn{11}{|l|}{ Age } \\
\hline $14-29$ & $54(65)$ & $17(20.5)$ & $20(24.1)$ & $17(20.5)$ & $13(15.7)$ & $12(14.5)$ & $06(7.2)$ & $23(27.7)$ & $21(25.3)$ & $33(39.7)$ \\
\hline $30-49$ & $29(34.9)$ & $03(36.3)$ & $17(20.5)$ & $08(9.6)$ & $02(2.4)$ & $04(4.8)$ & $03(3.6)$ & $2(24.1)$ & $20(24.1)$ & $09(10.8)$ \\
\hline \multicolumn{11}{|l|}{ Level of Study } \\
\hline Non level non & $2(2.4)$ & $0(0)$ & $01(1.2)$ & $01(5)$ & $0(0)$ & $01(1.2)$ & 0 & $01(2.2)$ & $02(3.5)$ & 0 \\
\hline Primary & $11(13.3)$ & $0(0)$ & $11(13.3)$ & $0(0)$ & $0(0)$ & $01(1.2)$ & $01(1.2)$ & $09(10.8)$ & $06(7.2)$ & $05(6)$ \\
\hline High School & $53(63.9)$ & $15(18)$ & $26(31.3)$ & $12(60)$ & $03(50)$ & $12(75)$ & $12(14.5)$ & $26(31.3)$ & $37(44.6)$ & $16(19.3)$ \\
\hline University & $17(20.4)$ & $05(6)$ & $05(6)$ & $07(8.4)$ & $03(3.6)$ & $02(2.4)$ & $03(3.6)$ & $09(20)$ & $12(14.5)$ & $05(6.0)$ \\
\hline \multicolumn{11}{|c|}{ Matrimonial Status } \\
\hline Single & $22(26.5)$ & $06(7.2)$ & $13(15.6)$ & $03(3.6)$ & $03(3.6)$ & $05(6)$ & $08(9.6)$ & $06(7.2)$ & $17(20.5)$ & $05(6.0)$ \\
\hline Maried & $61(73.5)$ & $14(16.8)$ & $34(40.9)$ & $17(20.4)$ & $04(4.8)$ & $12(14.5)$ & $09(10.8)$ & $36(43.4)$ & $42(50.6)$ & $19(22.9)$ \\
\hline \multicolumn{11}{|l|}{ Living standards } \\
\hline Low & $21(25.3)$ & $06(7.2)$ & $09(10.8)$ & $06(10.8)$ & $11(13.2)$ & $03(3.6)$ & 00 & $07(8.4)$ & $08(9.6)$ & $13(15.6)$ \\
\hline Average & 49 (59) & $16(19.2)$ & $19(22.9)$ & $14(16.9)$ & $09(10.8)$ & $09(10.8)$ & $25(30.1)$ & $06(7.2)$ & $29(34.9)$ & $20(24)$ \\
\hline Highly average & $13(15.7)$ & $06(7.2)$ & $03(3.6)$ & $04(4.8)$ & $02(2.4)$ & $05(6)$ & $04(4.8)$ & $01(1.2)$ & $06(7.2)$ & $07(8.4)$ \\
\hline \multicolumn{11}{|l|}{ Occupation } \\
\hline House wife & $63(75.9)$ & $06(7.2)$ & $34(40.9)$ & $13(15.6)$ & $08(9.6)$ & $17(20.5)$ & $10(66.7)$ & $28(33.4)$ & $42(50.6)$ & $21(25.3)$ \\
\hline Student & $6(7.2)$ & $02(2.4)$ & 00 & $04(4.8)$ & 0 & 0 & $02(2.4)$ & $04(4.8)$ & $06(7.2)$ & 0 \\
\hline Officers & $14(16.9)$ & $02(2.4)$ & $09(10.8)$ & $03(3.6)$ & $0(0)$ & $01(1.2)$ & $03(3.6)$ & $10(12)$ & $11(13.3)$ & $03(3.6)$ \\
\hline \multicolumn{11}{|l|}{ Gestity: } \\
\hline $1-3$ & $60(72.3)$ & $16(19.2)$ & $32(38.5)$ & $12(14.4)$ & $08(9.8)$ & $13(15.6)$ & $14(16.8)$ & $25(30.1)$ & $38(45.7)$ & $10(12)$ \\
\hline 4 et plus & $23(27.7)$ & $04(4.8)$ & $11(13.2)$ & $08(9.6)$ & $02(2.4)$ & $02(2.4)$ & $04(4.8)$ & $15(17.9)$ & $17(20.5)$ & $6(7.2)$ \\
\hline \multicolumn{11}{|l|}{ Gestational age } \\
\hline First trimester & $10(12.1)$ & 0 & $03(3.6)$ & $07(8.4)$ & 0 & 0 & 0 & $10(12)$ & $10(12)$ & 0 \\
\hline Second trimester & $23(27.7)$ & $02(2.4)$ & $16(19.3)$ & $05(6)$ & $02(2.4)$ & $05(6.2)$ & $01(1.2)$ & $15(18.1)$ & $17(20.5)$ & $06(7.2)$ \\
\hline Third trimester & $50(60.2)$ & $21(25.3)$ & $23(27.7)$ & $06(7.2)$ & $13(15.7)$ & $12(14.5)$ & $07(8.4)$ & $18(21.6)$ & $39(46.9)$ & $11(13.3)$ \\
\hline
\end{tabular}

BOP: Bleeding on probing; OHIS: Oral hygien index simplified; PDI: Periodontal disease index.

This study aimed to determine the frequency of periodontal disease and the risk factors associated in pregnant women. The main results of this study show that the overall frequency of periodontal disease is high in pregnant women (79\%) that mostly had 20 - 29 years of age, with an average economic status. The level of education and gestational age although were significantly associated with pe- 
riodontal diseases $(\mathrm{p}<0.005)$ to univariate analysis, however, only gestational age was determined as an independent factor associated with gingival bleeding in multivariate analysis $(\mathrm{p}<0.005)$. Most of the pregnant women had localized gravidities gingivitis without loss of attachment and periodontitis during all trimesters, but with a predominance in the third trimester. The high overall frequency of periodontal diseases in this study was corroborated with the study of Diawara et al. [21], and Tchonang [22] with respectively 91\%. This can be explained by the sexual hormonal action on periodontal tissues. Hormonal impregnation during pregnancy results in greater fluidity in the connective tissue matrix that lead to hypervascularization, edema tendency, and congestive state. Progesterone also acts on gum vascular permeability, inducing proliferation and vascular new formation. Thus, under the influence of hormones, the number of sub-gingival bacteria increases, and the immunodeficiency caused by the concentration of progesterone induces a reduction of IL-6, lower production of TIMPs, and an increase in proteolytic enzyme activity. The secretion of a higher level of TNF- $\alpha$ in periodontal tissues would promote the virulence of periodontal microorganisms and lead to more inflammation [23]. This modification of the connective periodontal tissues, combined with the accumulation of dental plaque, would promote the aggravation of periodontal diseases.

Based on the socio-demographic characteristics used in this study, the majority of pregnant women were $20-29$ years of age with an average age of $30( \pm$ SD 2.6) of which $73.4 \%$ of cases were married women, with an average socio-economic level (56.6\%) and a secondary education level (63.8\%). The present results were similar to the result of Tchonang [22] for the age group, and Diawara et al. [21], Keltoum et al. [24], Ibrahim et al. [25] for frequency. This age group is most affected because considered as the period of intense sexual activity among girls. Married women compared to other studies [23] [26], were numerous in this study. The study took place during the campaign launched by the Government of the Republic for the military officer's wives and the lack of entrepreneurship by these pregnant women does not allow them to tie the two ends of the month. From a clinical observation view, gum bleeding was detected during the pregnancy period, but with a high peak at the second trimester. The results corroborate those of other authors [25] [27]. The pain has high levels of concentration of sex hormones in the bloodstream, which partly explain tissue alterations. The risk of developing gingivitis varies depending on the plasma level of steroid hormones during pregnancy. Its increase leads to greater fluidity in connective tissues resulting in hypervascularization, an edematic tendency, and a congestive state that would accentuate pre-existing gingivitis. From the first to the third stage, the pregnant woman has poor oral hygiene, localized gravitic gingivitis without loss of clinical attachment. The level of oral hygiene assessed by the simplified oral hygiene index of pregnant women was $38.2 \%$ in the third trimester and a significant correlation between the age of the pregnancy and oral hygiene was observed as found by several authors [22] [24]. During the last month 
and the first 3 months in postpartum, there was a significant regression of gravidities gingivitis following a sharp drop in steroid hormone production [2] that was similar to the results of Tilakaratne et al. [28] and Taani et al. [29]. Some authors [22] [27] [30], showed that $38 \%$ to $93.8 \%$ of pregnant women had generalized gingivitis, observed at all ages of pregnancy. Similarly, according to the Periodontal Disease Index, the majority of pregnant women had gingivitis (69.6\%) compared to periodontitis (30.4\%) in the third trimester. Rosanna Hess [30] had found a rate of $24 \%$ of gingivitis and $49 \%$ of periodontitis in pregnant women in the first and second trimesters. Pregnant women tend to have significantly the pocket depth due to gum hypertrophy.

The present study is certainly the first to assess the periodontal diseases in the pregnant women of the Democratic Republic of Congo. However, it has some limits; the study did not observe and follow pregnant women until they were given birth. As a result, this study was unable to assess post-birth complications.

\section{Conclusion}

Periodontal impairments are common during pregnancy in our environment and they are favored by low socioeconomic and education levels. The periodontal diseases occur mainly in the third trimester and were significantly associated with gestational age in pregnant women. Bleeding is the most common symptom, especially in the second trimester.

\section{Conflicts of Interest}

The authors declare no conflicts of interest regarding the publication of this paper.

\section{References}

[1] Ahnoux, A., Aoussi, E., Anongha, D.S., Kone, D., Elradi, T. and Brou, E. (2003) Grossesse et Etat de Santé parodontale. Etude auprès de 133 femmes enceintes. Odontostomatologie Tropicale, 102, 37-40.

[2] Amarasena, N., Kapellas, K., Browa, A., Skitton, M., Maple-Brown, L.J., Bartol, M.P., et al. (2015) Psychological Distress and Self-Rated Oral Health among a Convenience Sample of Indigenous Australians. Journal of Public Health Dentistry, 75, 126-133. https://doi.org/10.1111/jphd.12080

[3] Chen, L., Lu, H.X., Wei, T.Y. and Feng, X.P. (2014) Multiple Factors Analysis of Periodontal Status in Pregnant Women in Shanghai. Shanghai Journal of Stomatology, 23, 452-456. (In Chinese)

[4] Agbo-Godeau, S. (2002) Stomatologie et grossesse. Encycl. Méd-chir, stomatologie 22-050-F-10, Gynecologie/Obstétrique, 5,045:10.

[5] Philstrom, B.L., Michalowicz, B.S. and Johnson, N.W. (2005) Periodontal Diseases. The Lancet, 366, 1809-1820. https://doi.org/10.1016/S0140-6736(05)67728-8

[6] Loe, H. and Silness, J.J. (1963) Periodontal Disease in Pregnancy I Prevalence and Severity. Acta Odontologica Scandinavica, 21, 533-551.

https://doi.org/10.3109/00016356309011240

[7] Vascnellas, et al. (2012) Periodontis-Associated Risk Factors in Pregnant Women. 
Clinics, 67, 27-33. https://doi.org/10.6061/clinics/2012(01)05

[8] Dinas, K., et al. (2007) Pregnancy and Oral Health: Utilisation of Dental Services during Pregnancy in Northern Greece. Acta Obstetricia et Gynecologica Scandinavica, 86, 938-944. https://doi.org/10.1080/00016340701371413

[9] Saddki, N., et al. (2010) Factors Associated with Dental Visit and Barriers to Utilisation of Oral Health Care Services in Sample of Antenatal Mothers in Hospital University Soins Malaysia. BMC Public Health, 10, 75.

https://doi.org/10.1186/1471-2458-10-75

[10] Diallo, B., China, E., Makoutode, M. and Coulibaly, C. (2014) Associated Factors with Periodontal Disease in Pregnant Women at the Hospital of the Mother and Child Lagoon (HOMEL) Cotonou. Mali Medical, 2, 43-47.

[11] Wandera, M., Astrøm, A.N., Okullo, I. and Tumwine, J.K. (2012) Determinants of Periodontal Health in Pregnant Women and Association with Infants Anthropometric Status: A Prospective Cohort Study from Eastern Uganda. BMC Pregnancy Childbirth, 12, Article No. 90. https://doi.org/10.1186/1471-2393-12-90

[12] Zi, M.Y., Longo, P.L., Bueno-Silva, B. and Mayer, M.P. (2015) Mechanisms Involved in the Association between Periodontitis and Complications in Pregnancy. Frontiers in Public Health, 2, 290. https://doi.org/10.3389/fpubh.2014.00290

[13] Muwazi, L., Rwenyonyi, C.M., Nkamba, M., Kutesa, A., Kagawa, M., Mugyenyi, G., et al. (2014) Periodontal Conditions, Low Birth Weight and Preterm Birth among Postpartum Mothers in Two Tertiary Health Facilities in Uganda. BMC Oral Health, 14, 42. https://doi.org/10.1186/1472-6831-14-42

[14] Cisse, D.M., Diouf, A.F., Diadhiou, M.F. and Tal-Dia, A. (2015) Periodontal Disease of Pregnant Women and Low Weight Newborn in Senegal: A Case-Control Study. Open Journal of Epidemiology, 5, 1-8. https://doi.org/10.4236/ojepi.2015.51001

[15] Ide, M. and Papapanou, P.N. (2013) Epidemiology of Association between Maternal Periodontal Disease and Adverse Pregnancy Outcomes-A Systematic Review. Journal of Clinical Periodontology, 40, S181-S194.

https://doi.org/10.1111/jcpe.12063

[16] Walia, M. and Saini, N. (2015) Relationship between Periodontal Diseases and Preterm birth: Recent Epidemiological and Biological Data. International Journal of Applied and Basic Medical Research, 5, 2-6. https://doi.org/10.4103/2229-516X.149217

[17] Nwhator, S.O., Opeodu, O.I., Ayanbadejo, P.O., Umeizudike, K.A., Olamijulo, J.A., Alade, G.O., et al. (2014) Could Periodontitis Affect Time to Conception? Annals of Medical and Health Science Research, 4, 817-822. https://doi.org/10.4103/2141-9248.141567

[18] Stadelmann, P.F.M., Eick, S., Salvi, G.E., Surbek, D., Mohr, S., Bürgin, W., et al. (2015) Increased Periodontal Inflammation in Women with Preterm Premature Rupture of Membranes. Clinical Oral Investigations, 19, 1537-1546. https://doi.org/10.1007/s00784-014-1371-6

[19] Kalala-Kazadi, E., Toma, S., Lasserre, J.F., Nyimi-Bushabu, F., Ntumba-Mulumba, H., et al. (2020) Clinical and Microbiological Profiles of Aggressive and Chronic Periodontitis in Congolese Patients: A Cross-Sectional Study. Journal of International Society of Preventive \& Community Dentistry, 10, 491-497. https://doi.org/10.4103/jispcd.JISPCD_501_19

[20] Kalala, E.K., Fidèle, B., Béatrice, K., Sekele, J.-P., Alain, K., Pierre, M., et al. (2018) Frequency and Profile of Severe Periodontitis in Kinshasa Dental Hospitals, DR 
Congo. Health, 10, 396-402. https://doi.org/10.4236/health.2018.104032

[21] Diawara, O., Kane, A.S.T., Niangi, A., et al. (2018) Periodontal Health in Pregnant Women Study of 208 Pregnancies at Chu Gabriel Touré. Bamako. Mali. https://doi.org/10.53597/remim.v0i9.931

[22] Tchonang Mani Estelle Danielle (2007) Les manifestations parodontales chez la femme enceinte en consultation prénatale dans le service de gyneco-obstretrique du Chu Gabriel Toure: 208 cas. Thèse, 16-32.

[23] Figuero, E., Carnillo-de-Alornoz, A., Herrera, D. and Bascones Martinez, A. (2010) Gingival Changes during Pregnancy: I. Influence of Hormonal Variations on Clinical and Immunological Parameters. Journal of Clinical Periodontology, 37, 220-229. https://doi.org/10.1111/j.1600-051X.2009.01516.x

[24] Keltoum, A., Naima, S. and Zabr, B. (2016) Profil clinique et épidémiologique des maladies parodontales chez la femme enceinte au niveau du service de parodontologie du centre Hospitalo-Universitaire de Tlemcen, 34.

[25] Mwangosi, I.E.A.T. and Kiango, M.M. (2012) Oral Health Experience during Pregnancy and Dental Service Utilization in Bariadi District, Tanzania. Tanzania Journal of Health Research, 14, 1-7. https://doi.org/10.4314/thrb.v14i2.8

[26] Nabet, C., Lelong, N., Colombier, M.L., Sixoui, M., Musset, A.M., Goffinet, F., et al. (2010) Maternal Periodontitis and the Causes of Preterm Birth: The Case-Control Epipap Study. Journal of Clinical Periodontology, 8, 11-13.

[27] Bengondo, M.C., Minkande, Z.E., Mengong, H.P., Pisoh, T.C., Onana, J. and Essana, E.B. (2006) Pathologie bucco-dentaire de la femme enceinte en milieu Camerounais. Clinics in Mother and Child Health, 3, 449-452.

[28] Tilakaratne, A., Soory, M., Ranasinghe, A.W., Corea, S.M.X., Ekanayake, S.L. and De Silva, M. (2000) Periodontal Disease Status during Pregnancy and 3 Months Post-Partum, in a Rural Population of Sri-Lankan Women. Journal of Clinical Periodontology, 27, 787-792. https://doi.org/10.1034/j.1600-051x.2000.027010787.x

[29] Taani, D.Q., Habashneh, R., Hammad, M.M. and Batieha, A. (2003) The Periodontal Status of Pregnant Women and Its Relationship with Socio-Demographic and Clinical Variables. Journal of Oral Rehabilitation, 30, 440-445. https://doi.org/10.1046/j.1365-2842.2003.01058.x

[30] Bieri, R.A., Adriaens, L., Sorri, P., Lang, S.N. and Persson, G.R. (2013) Gingival Fluid Cytokine Expression and Subgingival Bacterial Counts during Pregnancy and Postpartum: A Case Series. Clinical Oral Investigations, 17, 19-28.

https://doi.org/10.1007/s00784-012-0674-8 